\title{
Five Chess Positions to Learn Law and Legal Argumentation
}

\author{
Salvador Peran \\ $\mathrm{PhD}$ in Law, University of Málaga \\ Facultad de Estudios Sociales \\ Ampliación Campus de Teatinos, Madrid, Spain
}

Doi: 10.19044/ejes.v6no1a8

URL:http://dx.doi.org/10.19044/ejes.v6no1a8

\begin{abstract}
Law students should be able to fathom the application of legal rules to specific cases and develop a consistent argumentation to support this interpretation by using logic. Different skills and competencies are required for each of these processes. Therefore, effective learning of Law must complement the necessary knowledge of Positive Law with a set of teaching activities aimed at developing a well-structured legal discourse. Can chess be useful when deducing the general features of legal argumentation? Can we use certain positions or chess moves as a basis for the elaboration of didactic metaphors capable of creating dynamic learning environments? We shall present five chess positions in this paper, which we shall use as a teaching resource to extract ideas regarding how legal discourse is structured.
\end{abstract}

Keywords: Chess, learning, Law, teaching resource, legal argumentation, teaching metaphors.

\section{DIDACTIC CHESS AS A TEACHING TOOL FOR LEARNING LAW. PRESENTATION, DESCRIPTION AND METHODOLOGY OF THE ACTIVITY}

There is a set of cross-sectional competencies in legal learning for which our curricula are not well prepared. Few or no teaching activities aimed at acquiring the basic knowledge of legal argumentation, the capacity for critical awareness in the analysis of the legal system and legal dialectics, or the development of legal oratory have been devised. However, it is common for our curricula to underline the importance of Law students being able to express themselves appropriately in front of an audience, to solve problems and adapt to new situations, develop creativity, or being able to organise, analyse and synthesise, and transmit conclusions.

In subjects related to Law, practical activities in which theoretical 
knowledge and this set of cross-sectional competencies are applied should be considered further, so that students may learn how to solve practical cases through legal arguments. It is common for Law students to emphasise their difficulties when presenting their conclusions on a specific practical case, especially as regards how to develop an appropriate plan or strategy to defend their point of view.

Imagine we have a teaching resource at our disposal that would allow us to improve students' concentration, but at the same time, stimulate memory, logical reasoning, scientific thinking, self-criticism, personal responsibility, motivation, self-esteem, planning, forecasting of consequences, the ability to calculate, imagination, creativity, patience, discipline, tenacity, attention to several things at once, the calculation of risks, sportsmanship, coldbloodedness, compliance with rules, respect for opponents, spatial vision and combativeness (García, L.; 2013). We would have pretty few excuses not to look for ways to integrate it into our classrooms.

There are numerous teaching experiences and studies that point to chess as a useful and cross-sectional instrument to improve memory, strategic thinking or mathematical calculation skills in school age (Fernández, 2016). Chess is known for being beneficial to develop cognitive intelligence (Gliga; Flesner, 2014), but also to develop true emotional intelligence (Aciego; et al., 2012). A sample of the importance that educational chess is acquiring nowadays can be seen in the Declaration of the European Parliament of 15 March 2012 on the introduction of the programme called Chess in School in the educational systems of the European Union. This programme promotes actions aimed at developing educational chess in primary education systems in the countries of the European Union.

There is no doubt about the need to incorporate chess as a complementary activity in schools in a clear and determined way, but this is not exactly what is proposed here. In this activity, students will not actually play chess games among themselves, but rather they will have to solve a set of proposed problems and draw conclusions applicable to devising legal discourse and collectively develop a metaphor of how a good legal argumentation should be. Indeed, tactical or theoretical elements of chess are not going to be explored in depth. Instead, it is expected that students will be able to devise metaphors of how a correct legal argumentation should be structured based on playing chess.

Five simple chess exercises are, therefore, proposed, which should be discussed and resolved by the students. They are presented in the form of worksheets or teaching resources and contain:

a) A short chess description of the position (positions have a variable difficulty, and some require a specific knowledge and prior analysis of the position, and others are beginner's level). 
b) A small historical account that allows us to cover such prestigious events as the Enlightenment, the Great Empires of East and West, the French Revolution, the War of Independence of the United States, the philosophical movements of the $20^{\text {th }}$ century, the decolonisation processes or the Cold War. There is no doubt that a universal game with at least fifteen centuries of history can serve as an ideal excuse to travel through history. Its own evolution shows us the importance of knowing the historicity of social events and the social uniqueness of each historical period.

c) An aphorism of the Spanish golden age author Baltasar Gracián. This allows contextualising and completing the activity and gives it a special attraction.

Didactic chess is a very interesting resource, easily adaptable to very diverse educational contexts and very simple to implement and use. The positions proposed here include a link from each item cited to a database with the diagram of the game. The singularity of this proposal is to relate chess to the creation of a dynamic learning environment, where students unquestionably take on the leading role, work on communicative skills, and encourage learning through the collective development of didactic metaphors. The intention with the use of educational metaphors is to favour the acquisition of knowledge from concepts not directly related to them (Kövecses, 2010), using knowledge of the source as a framework to give meaning to the objective question. This permits identifying the parts of the metaphor and visualise how they are interrelated. We are thus able to further understand the abstract from the concrete (Lakoff; Johnson, 1999).

Educational metaphors must be effective and to be effective, they must be able to create systematic associations between the elements of the objective and the analogous aspects of the source. The degree to which semantic or semiotic content is explicit will determine its level of effectiveness (Dunn, 2011). To reinforce their intuitive character, chess positions, which in themselves imply a high level of conceptual abstraction, will be reinforced by linguistic expressions -in the form of Gracián's aphorisms- from which the underlying conceptual meaning can be fathomed more clearly. Thus, the density of a metaphorical expression will depend on the amount of underlying metaphor that appears in the semantic or superficial semiotic structure for the particular social group.

While the understanding of metaphorical expression depends on the group's specific ontological knowledge of the essential elements of the source, the level of effectiveness of these activities cannot be determined a priori because it depends on the cultural and intellectual level of the target group.

The activities also intend to stimulate students' creativity and their ability to solve complex problems. The aim is, therefore, to encourage debate on a fairly logical principle. The clearer and more orderly the argumentation, the better the purpose of the process will be satisfied in attaining justice. In 
this vein, for legal discourse to be precise, reasonable and effective, it must be based on the art of prudence, synthesis, patience, detachment and rectification.

\section{THE METAPHORICAL FORCE OF CHESS AS A TEACHING TOOL FOR LEARNING LEGAL ARGUMENTATION}

Chess, as a simple model of social phenomenon (Ross, 1958), shows elements common to logic and legal argumentation alike. If we start by saying that for any legal argumentation to be valid it requires sufficient normativesocial grounds, such validity derives from elements extrinsic to the mere force or binding character of the norm. Therefore, the juridical problem, as a regulating element of a social body, is based on a set of normative principles of historical and social character, which allow a unique interpretation of the rules applicable to each case in question. In chess, as in legal argumentation, the connection between the movements of the chess pieces is not causal but of meaning. We do not change the positions of the pieces on the board randomly but as a result of strategic gameplay movements, which makes it a coherent plane of meaning, where movements become attack or defence actions as per the theoretical principles of the game.

At the same time, from a formal point of view, chess contains a set of imperative rules that regulate or determine the movements each piece can make. This does not prevent there being a unique space for the theoretical aspects of the game, which determine the strategic and functional character (Nunn, 2003) of each piece at any given time depending on a given position. Both planes establish the juridical character of chess and its relevance when devising metaphors on legal argumentation. Just as chess theory incorporates subjectivity and historicity into its normative framework, legal argumentation incorporates it into Law.

The combination of strategic and tactical chess principles prolifically defined by chess theory with elements of the judicial process is appropriate for university Law students. Strategic chess thinking allows lawyers to improve their skills in judicial processes, both in the field of interrogation and in legal psychology (Postma, 2004), and they share the principle of sufficient reasoning (Fernández, 2010).

If we take legal conflict as a reference, we can affirm that Law is argumentation (Atienza, 2006) and that there is no legal practice, which does not consist, substantially, of arguing. For this reason, any legal argument requires a set of coherent reasons, in favour or against a particular thesis that must be sustained or refuted, and interrelated in a strategic and logical way. As in a chess game, any legal agent that devises a legal argument must develop strategic thinking that structures normative interpretations in a consistent, coherent, exhaustive, teleological way, based on sufficient reasoning and the ideal knowledge about the case that is the subject matter of the argument. 
Analysing the situation -knowing how a given fact has legal relevance- is one thing and another, quite different, is to give a solution -by submitting it to a process of justifying possible interpretations, weighing up arguments for and against every possible interpretation-. The interpretative and application processes of legal norms are not possible without the use of argumentation (Zapatero; Garrido, 2007) and rational justification.

\section{EVALUATION OF THE ACTIVITY}

The activity has been evaluated by a group of students enrolled in the Social Security Law subject (49 students in total), who were asked to evaluate different elements through a descriptive survey with eight closed questions on a scale of 1-10. Although, neither the sample nor the methodology used intends to demonstrate the effectiveness of didactic chess in learning Law, they do allow collating relevant information on students' perception of the activity. Multiple-choice questions were used given their ease of use and processing. They were prepared according to the classifications, cataloguing and methodology used to evaluate higher education students' satisfaction (Marsh, H. W., 1982) and the evaluation survey of the Department of Education of the Junta de Andalucía (Spain) on their training actions. Naturally, there are many other alternatives, often more enriching than multiple-choice questions (Angelo, T. A.; Cross, P., 1993), which should be incorporated in the future. In any case, we must not forget that this paper aims to present a set of teaching resources in the form of chess pieces, which can and must be adapted to each educational context in a flexible manner.

First, they were asked to assess their level of chess. A subjective answer was sought with this, that is, to give their perception of their level of chess. In this vein, they did not receive any indication that could influence their answer one way or another (a determined ELO, membership in a chess club, mere knowledge of the rules, etc.) and the average score they awarded themselves was 4.55 .

It is worth noticing the distribution of the data according to their knowledge of chess. $28.57 \%$ of the sample showed having the lowest possible chess level (1-2), while the largest group (34.69\%) stated having an intermediate level (5-6). It is also interesting to note that the group with the highest score in chess knowledge was 7-8 (24.49\%) and no student selected the highest score (9-10), and only $12.24 \%$ selected between 3-4. 


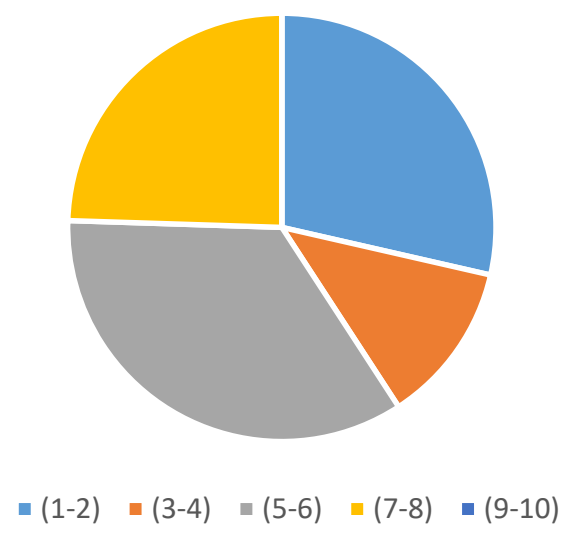

A) Overall assessment of the activity. The questionnaire contained a block of three questions about an overall assessment of the activity, the degree of understanding and the degree of difficulty. The activity was assessed globally with a mean score of 7.45. The mean score awarded to understanding was 7.67, and the mean score for difficulty was 4.63 .

B) Overall assessment of chess positions. In another block, students were asked to evaluate the appropriateness of the different chess positions proposed to understand the concept to be analysed. In general, the positions received a mean score of 6.73 .

We can see a certain deviation between the overall evaluation of the activity and the overall evaluation of the five positions. Both the median and the mode of the overall evaluation were 8 , while for the different positions it was 7. 69.38\% of students gave an overall score of between 7-9 to the activity, whereas $67.34 \%$ gave an overall score of between 6-8 to the chess positions.

C) Overall assessment of educational metaphors and didactic chess. Students were also asked to evaluate the two main teaching tools used in the activity, such as the usefulness of teaching metaphors and didactic chess for learning Law. Students evaluated the use of teaching metaphors for learning with a mean score of 6.91 and didactic chess as a suitable teaching tool for learning Law with a mean score of 6.12.

D) Overall assessment of the capacity to promote creativity in the Law Degree. Complementarily, students had to value the encouragement of creativity in the degree they were studying and yielded a mean score of 3.35.

The most significant data are deduced when discriminated against according to the level of chess the students stated having. Students who awarded themselves the lowest score in chess (1-2) are those who show: a) A lower degree of understanding of the activity (7.07), which represents 1.09 points less in understanding of the activity than the group with greater knowledge of chess, and 0.49 less than the average; b) They indicate a greater 
degree of difficulty of the activity (6.64), which means a standard deviation of 2.01 from the mean score and 3.31 points compared to the group with greater knowledge of chess; c) They give a lower overall score to the activity (6.5), which is 0.95 points lower than the mean score and 1.25 points lower than the mean score of the group with greater knowledge.

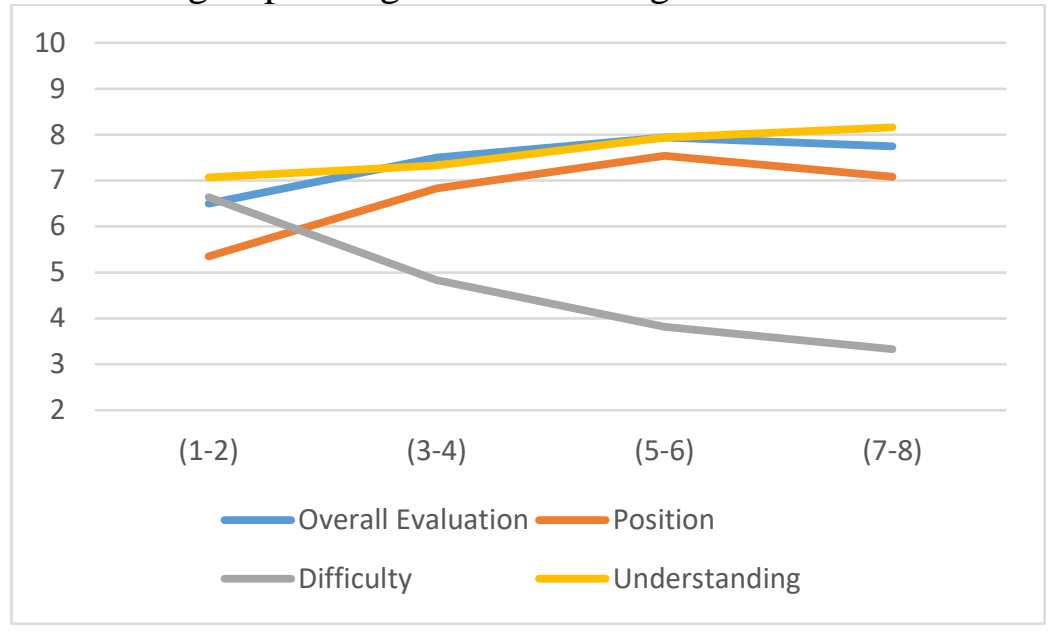

Similarly, the group of students with less chess knowledge shows deviations: a) In the overall evaluation of the positions, since they give an overall score of 5.35 to the positions, where the deviation with respect to the average is 1.38 points; b) In the evaluation of the teaching metaphor as a didactic instrument, which is valued with 6 points, resulting in a deviation of 0.91; c) In the evaluation of didactic chess as an instrument for learning Law, which is awarded a score of 4.5 , leading to a deviation of 1.62 .

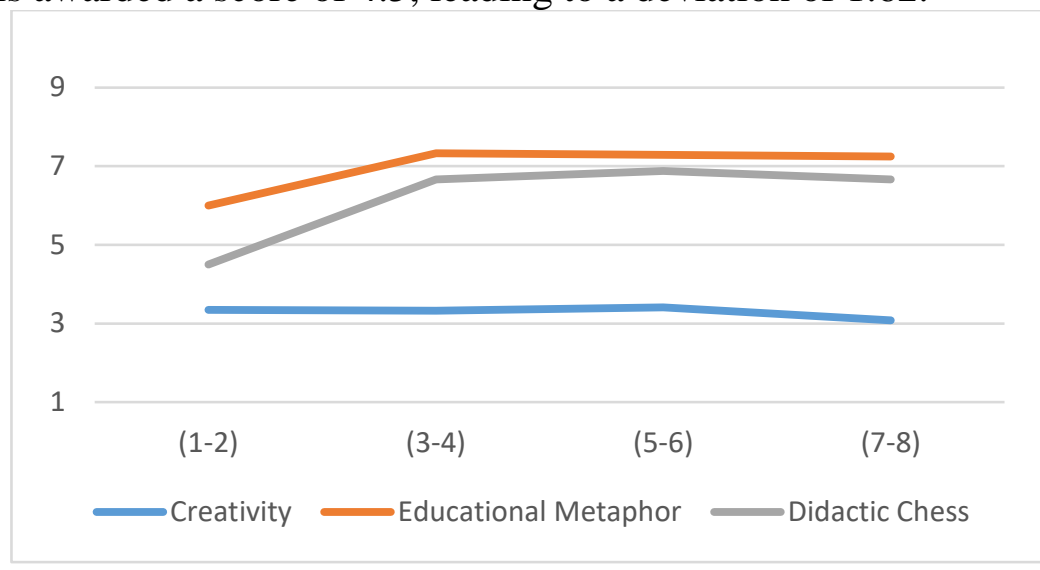

Finally, the only item where there are no deviations according to students' prior knowledge of chess is the one that refers to the existence of activities in the degree that stimulate students' creativity. Here, the group that shows the greatest deviation from the average is the one that has the highest 
knowledge of chess, the one that awards themselves 0.26 points less than the mean score.

With regard to the different positions, although the tendency in the students' assessment is upward according to the increase in chess knowledge, it is true that students with the greatest chess knowledge do not represent the group that gives the highest scores to the positions, but the group of 5-6, with an average deviation between them of 0.5. Group 5-6 was the one that gave the greatest value to the activity of worksheet 1 (Münchausen), 4 (Capablanca) and 5 (Alekhine), while the group that valued activity 2 (Légal) most was group 3-4, and the group that valued activity 3 (Nimzovich) most was group 7-8.

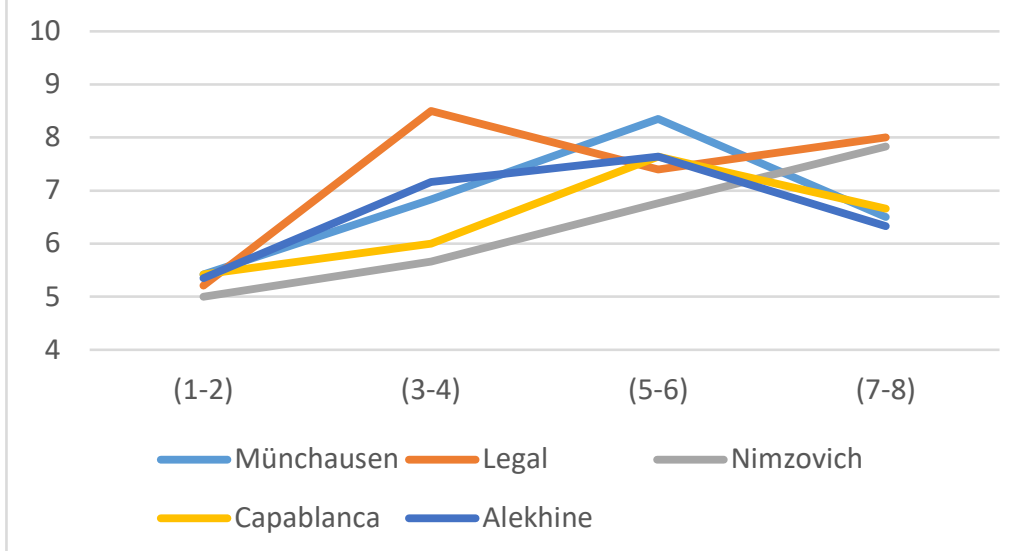

There is a positive correlation between the overall evaluation and the understanding of the activity, and a negative correlation between both items and the perception of the difficulty of the activity depending on the level of chess. This means that this activity does require a certain knowledge of chess. Significant deviations are described in the group that manifests less knowledge of chess, since the other groups have a more homogeneous behaviour although this also shows the ascending tendency both in the evaluation and in the understanding or difficulty, depending on their level of chess-. The higher the level of chess, the greater the understanding, overall assessment and lower the perception of difficulty.

\section{WORKSHEET I. THE ART OF SYNTHESIS}

\section{A Baltasar Gracián aphorism: Good things, when short, are twice as good. Student's activity}

The Baron of Münchausen met with some great chess masters in the court of Catherine II of Russia and proposed the following challenge. He would exchange one chess piece for each extra go he was granted, so the Baron would surrender the two rooks, the two bishops, the Queen and a Knight for 
six goes. Notice the following image, would you be able to checkmate with White moving six times consecutively?

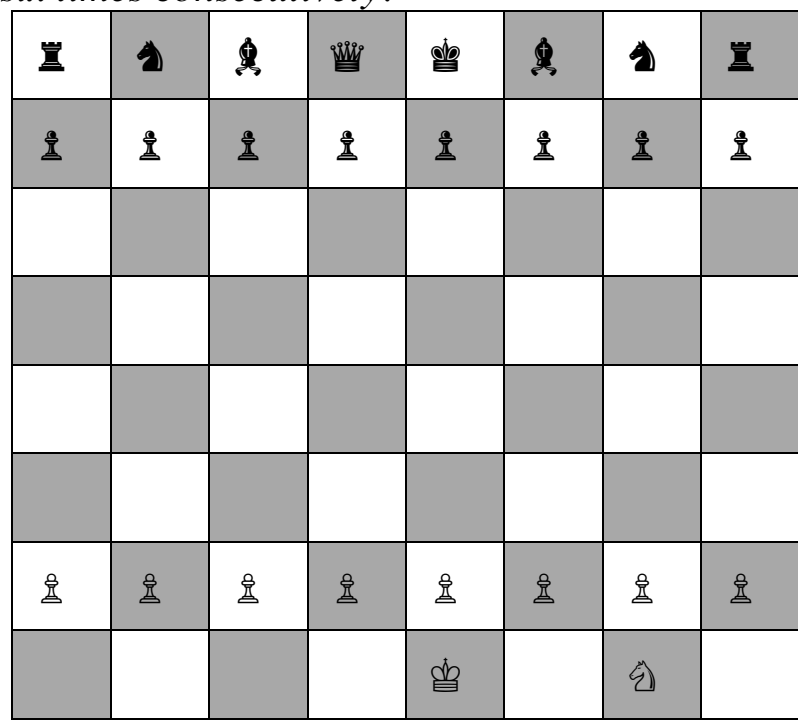

Baron of Münchausen

\section{A brief description of the position (teaching resource):}

What chess player would not dream of having more than one move per go?

\section{A brief historical context (teaching resource):}

In 1785, Rudolf Erich Raspe published Baron Münchausen's Narrative of his Marvellous Travels and Campaigns in Russia, a work that was later translated and versioned by Gottfried August Bürger in Wonderful journeys by land and by sea, war and fun adventures of the Baron of Münchausen. They were very modern stories of fantastic adventures -quite fashionable for the unbiased readers of the time- in which surprising events are told -he travels to the moon, over a canyon or to the centre of the earth-. A Baron of Münchhausen did exist. He enlisted in the Russian army and served as an inspiration for this clearly exaggerated and burlesque character. There have been several versions of this character throughout history, although this problem does not belong to the original text, other logical problems related to chess and openings have appeared. For instance, he devises a very ingenious paradox through a checkmate that is developed after Black repeats each of White's moves.

The $18^{\text {th }}$ century was the century of lights and illustration, and the travels described in this book show the balance and political conflict between the great empires -Prussian, Russian and Ottoman-; a small sample of the passage from the modern to the contemporary age. 


\section{Solution:}

1.Nf3 2.Ng5 3.e4 4.e5 5.e6 6.exf7++

\section{Objectives of the reflection:}

When preparing a legal discourse, it is crucial to know how to be sparing with the available resources, both in cognitive and material terms. One must be able to synthesise and prioritise ideas and make the most appropriate use of time and other resources. The principle of procedural economy is a general political-procedural principle that informs the jurisprudential activity and is characterised by the simplification and facilitation of the procedural activity in order to achieve the least possible wear and tear in the judicial process. This means that unnecessary and ancillary elements must be removed in the interests of an agile and efficient procedure.

This too is a basic principle of chess. This game teaches the importance of knowing how to take advantage of each of the moves, knowing how to select the most necessary in each moment within the general strategy. Another clearly connected idea is the principle of sobriety. In chess, it is said that there is no time for artificial or frivolous moves (Nimzovich, 1925). On the same lines: in a good argument, everything is superfluous except the indispensable.

\section{WORKSHEET II. THE ART OF PRUDENCE}

A Baltasar Gracián aphorism: Think twice; reflection arrives where apprehension failed.

Student activity:

White plays: Kxe5. Black can capture the White Queen if he wants to but, is it the best option? 


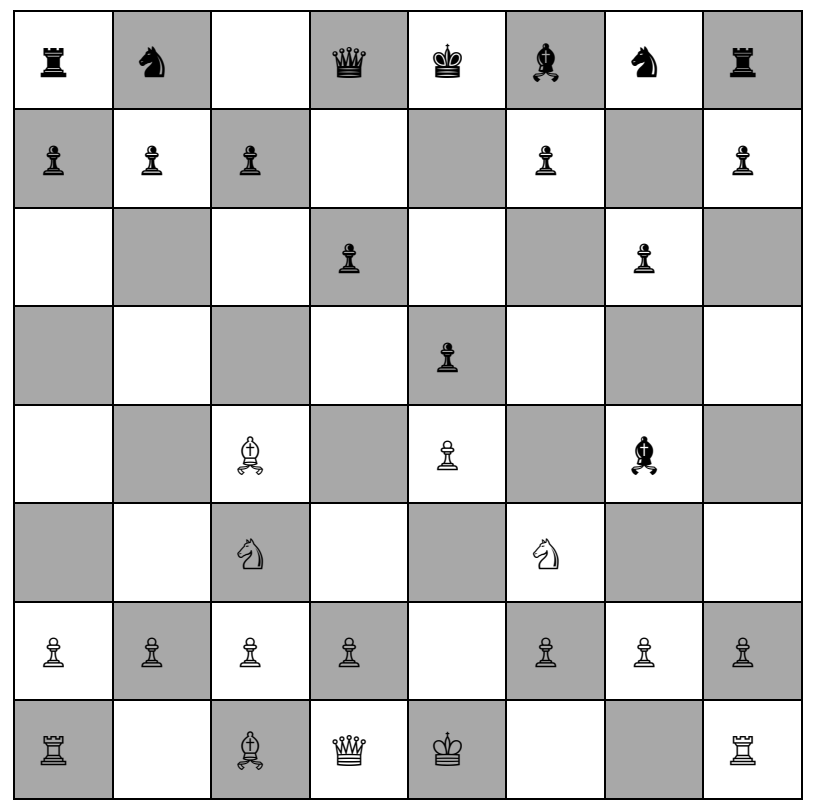

Légal - Saint Brie - Paris, 1750

\section{A brief description of the position (teaching resource):}

White has initiated an Italian opening characterised by the Pawn on e4, Bishop on c4 (developing towards the weak point f7, which can only be defended by the King) and Knight on $\mathrm{f3}$ (which, in turn, puts pressure on the Pawn on e5). He also made a move with the usual development - Knight c3.

Black strategised the Philidor Defence, because, after e5, d6 aims to strengthen this position. In addition, he made two plays of a different sign, g6 -a rather doubtful move, no doubt thinking of "fianchettoing" the Bishop on f8 or perhaps preparing a possible break on f5, and Bishop on g4, with which he intends to "pin" the Knight, so that, if the Knight moves, there is a clear path to capture the Queen. Legend has it that Légal, upon discovering the combination, caressed his "pinned" Knight very slightly and carefreely, before his opponent demanded he moved the Knight by the rule of "piece touched piece moved". The outcome is well known.

\section{A brief historical context (teaching resource):}

We are in the pre-revolutionary Paris and some places that will soon revitalise the cultural, social and intellectual life of the city are beginning to appear, the so-called cafés. Légal's mate is one of the most beautiful and famous checkmates in the history of chess. The game was held in the great Mecca of chess of the time, café Régence in Paris. We can imagine watching the game, while betting or discussing art and politics with Robespierre, Napoleon Bonaparte, Voltaire or Diderot, regulars of this café. In this same 
café Karl Marx would meet Friedrich Engels, but this time in another location and a century later.

We said that Black took the Philidorf defence, although it was not called this at that time. Bear in mind that the Grand Master Philidorf was 24 years old then and as a good disciple, he was very attentive to the moves his master Légal made in his games at café Régence. Philidorf -a close friend of Benjamin Franklin's, when he was US ambassador to Paris- was considered the world's greatest player at the time and a great game theorist.

The outcome of the game:

5... - Bxd1: Black decides to capture the White Queen. A serious mistake!

$6 \mathrm{Bxf7}+$ - Ke7

$7 \mathrm{Nd} 5++$

\section{Objectives of the reflection:}

Légal's famous checkmate threatens the board. This position is interesting because Black -who loses the game- is so engrossed in capturing the White Queen yet fails to see the trap it involves. Black is fully convinced of the goodness of his action so much so that he is unable to shuffle the weaknesses of his position and the consequences of capturing the Queen. The principle of prophylaxis is basic in chess and helps assess the risks involved in each new position on the board, especially avoiding the opposite's development and preventing threats that this may entail. In chess, it is said that the defencelessness of our pieces leads to the successful combination of our opponent. This game is a good lesson for a Law student when writing an argument. Reflective thought implies this exercise of caution. A good lawyer should be aware of the convenience of assessing the pros and cons of any argument, the need to develop strategic thinking, the importance of prudence and the importance of some material detachment.

\section{Diagram of the game:}

http://www.chessgames.com/perl/chessgame?gid=1251892

WORKSHEET III. THE ART OF RECTIFICATION

A Baltasar Gracián aphorism: Do not double the foolishness, never continue, by obstinacy, the worst game

Student's activity:

The Black King is threatened, and it is Black's turn. What would be the best move? 


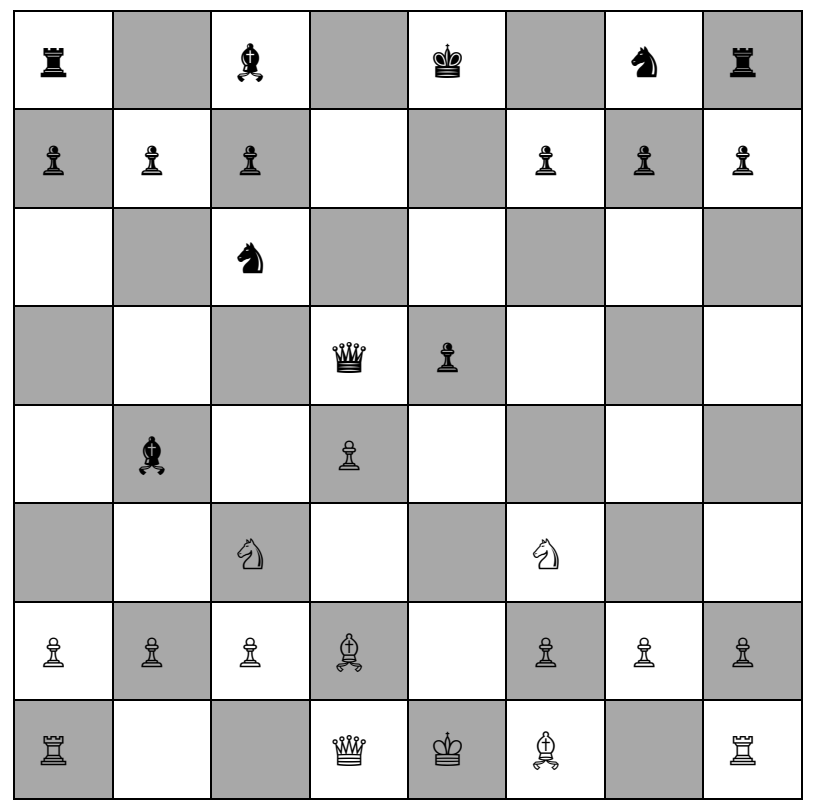

Aarón Nimzovich, Mein System, 1925

\section{A brief description of the position (teaching resource):}

This is a theoretical position put forward by Nimzovich to explain the importance of simplifying and eliminating tension, as well as the need to know how to let go of a bad idea in time. This position highlights the Queen's centrality in the opening, an unlikely circumstance since the enemy will tend to look for moves that allow creating threats to the Queen while developing his pieces. This forces us to waste time protecting our Queen while they seek good positions for their minor pieces.

\section{A brief historical context (teaching resource):}

Nimzovich was one of the foremost promoters of the hypermodern revolution that implied a new philosophy of chess. They questioned some fundamental principles of positional theories, and beyond some conceptual excesses, their contributions to the progress of the game have been paramount. His game is based on flexibility, a well-designed plan that may change when least expected and on concepts such as prophylaxis, centralisation and blocking.

Hypermodern theories were developed in the early twentieth century together with other philosophical, political and cultural movements capable of creating a crisis around the basic notions of modernity and which have shaped the new collective subjectivities that characterise our times. The avant-garde, postmodern theories and the birth of new social concerns such as feminism and ecology are good examples. 


\section{Solution:}

\section{6... Вxс3 7 Bxс3}

\section{Objectives of the reflection:}

"To rectify is of wise people" is a very appropriate principle to apply to any facet of our lives, and little more can be added to Gracián's wise aphorism that serves us as a title: do not double the foolishness, never continue, by obstinacy, the worst game. Juridically, it can be characterised by flexibility in the claims and by the ability to mediate and negotiate.

\section{WORKSHEET IV. THE ART OF PATIENCE}

A Baltasar Gracián aphorism: Hastening the victory, knowing how to manage expectations

Student activity:

Black has captured the White Knight on $\mathrm{f} 4$ but... Should Black capture the Bishop on $\mathrm{f} 4$ with the Pawn?

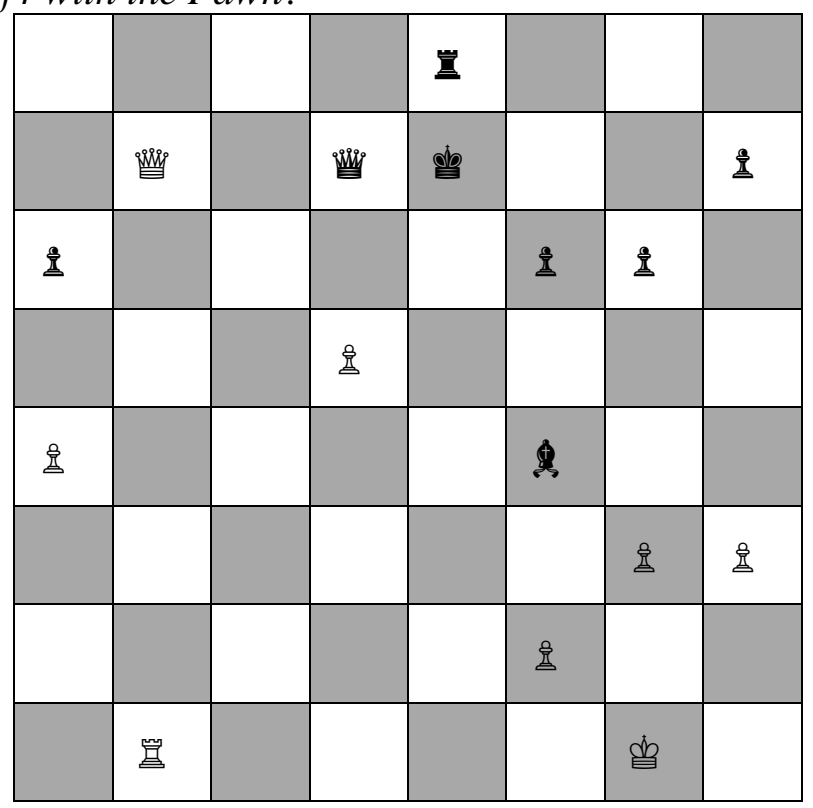

Capablanca \& Zubárev - Moscow, 1925

\section{A brief description of the position (teaching resource):}

Capablanca was a great positional player. Note that while his King is perfectly sheltered on g1, the Black King is in an uncomfortable position on e7 -in an open column in front of his Rook and with his Queen "pinned" by the White Queen-. Zubérev captures $\mathrm{f} 4$ with the Black Bishop hoping perhaps that Capablanca will capture the g3 Pawn in return. He aims to eliminate tension through change and to achieve a much more balanced position. 
For his part, José Raúl Capablanca seeks to maintain the tension and threats in pursuit of either leading the enemy King to a mate position (maybe with the support of the Pawn on g3) or to capture the Queen. This constitutes a decisive advantage that leads to the abandonment of his rival (which is what ends up happening), for he will look for checks consecutively -nine in totaluntil he succeeds in placing the Black King where he wants it, at which time it will set him off.

\section{A brief historical context (teaching resource):}

Capablanca looks like a character out of a Scott Fitzgerald novel, elegant and cultured. He was certainly an unexpected master. The great Latin American chess player, born in a small Caribbean island (Cuba), recently independent from Spain and immersed in a dictatorship under the protection of the USA. He was the son of a Spanish soldier, and his father supported the Creole rebellion against the colonising force, something that would undoubtedly influence his deep Cuban nationalist sentiment and leading him to become one of the undisputed historical figures on the island. The Cuban poet, Nicolás Guillén, wrote Cuba flies in the afternoon like a sad dove, after his death.

The game took place in Moscow in 1925. It was the first ever great chess championship to be held by the USSR, and the Cuban government tried to prevent Capablanca's from participating, but to no avail. Chess became an instrument with which to demonstrate the "superiority" of each side during the Cold War. The high point of this USSR-US confrontation was undoubtedly the historic Fischer-Spassky duel of 1972, considered the game of the century.

\section{The outcome of the game:}

34. Re1+-Be6 35. d6+-Ke6 36. Qb3+-Kf5 37. Qd3+-Kg5 38. Qe3+-Kf5 39. Qe4+-Ke6

40. Qc4+-Kxd6 41. Rd1+-Ke7 42. Rxd7+-Kxd7 43. Qxa6 -1-0

\section{Objectives of the reflection:}

It is just as important to have a good argument, as it is to know how to get the most out of it. In chess, advantageous positions are frequently disrupted, due to haste and the desire to capture an unimportant piece. Chess trains you to make the most of the positional advantages and to know how to bring an argument to its ultimate consequences. Managing advantages is not always easy. Certainly, a good argument requires a greater effort to know how to choose the most appropriate outcome and take all its power.

\section{Diagram of the game:}

http://www.chessgames.com/perl/chessgame?gid=1100093 


\section{WORKSHEET V. THE ART OF DETACHMENT}

Ignorance does not see beyond the shell; one should not get carried away by the first impression.

Student activity:

White plays and wins. Discover White’s winning combination.

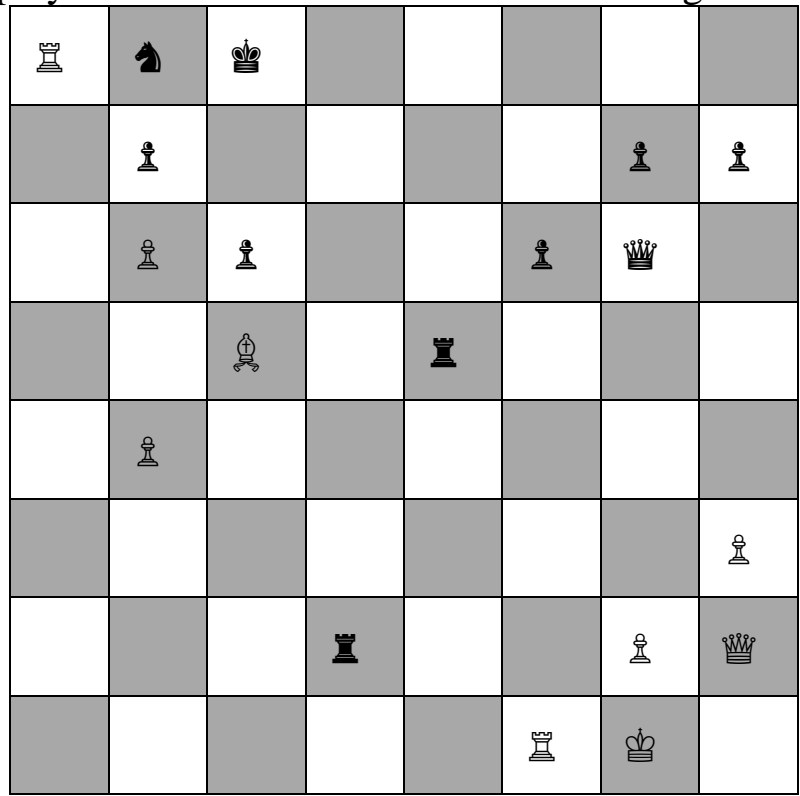

Alekhine \& Reshevsky, Kemeri, 1937

\section{A brief description of the position (teaching resource):}

From White's point of view, we have a powerful Rook on the eighth row, a powerful Pawn on b6 -this figure is called Damiano's Pawn, and it is going to be a very active piece in the combination, since it avoids key squares for a possible escape from the King-, a powerful Bishop on c5 and an active Queen on h2, controlling an important diagonal, and threatening a definitive attack -if it were not for the Rook on e5 that stands in its way-.

On the other hand, Black threatens checkmate with the Rook on e2 and the Queen of g6 on g2 as soon as the White Queen who defends that point becomes distracted, having, on the other hand, the weaknesses previously mentioned and especially the pinned Knight on b8.

\section{A brief historical context (teaching resource):}

The two protagonists of this game were exiled, marked by the European totalitarianism of the $20^{\text {th }}$ century. Dr Alekhine was the fourth world champion, famous for his aggressive play. Legend has it that he earned his $\mathrm{PhD}$ in Law from the Sorbonne in Paris. Russian-born and from the bourgeois class, he was arrested in 1920 for supporting the White Army. In prison, he played one of the "most famous" games in history against the "village 
commissioner", Leon Trotski, who visited him in his cell in Odessa. Dr Alekhine defeated him in that game and was awarded the letter of release the very next day. He later obtained a visa to leave Russia and settled in France, obtaining his nationality.

Reshevsky, for his part, was a Polish chess player of Jewish origin, who became a United States national because his parents emigrated to the United States. He also starred in big games against Bobby Fischer.

\section{The outcome of the game:}

35. Rxb8+: The Rook is surrendered to attract the King to b8.

... Kxb8: He accepts the sacrifice.

36. Qxe5+: A new sacrifice... This time, the Queen!

... 1-0: Black abandons since, after the capture of the Queen by the Pawn on f6, the Rook f8 comes and... Checkmate!

\section{Objectives of the reflection:}

In this position, the key piece to obtain a mate will be the advanced Pawn on b6. In chess, it is very important to develop a certain detachment for the material value of the pieces, as it is more interesting to discover the functional value of each of them in each specific situation within a global strategy. The mate is obtained after a double sacrifice of the Rook and the Queen, where the combination of the Rook and the Pawn -the piece of lesser value- is what gives the checkmate.

In legal disputes, a deep understanding of the problem at stake is key. Arguments are interrelated by creating a logical reasoning aimed at obtaining a specific result. The relationship between the arguments must, therefore, be functional, in order to refute or defend a specific assumption.

\section{Diagram of the game:}

http://www.chessgames.com/perl/chessgame?gid=1013251

\section{Conclusion}

We can use certain positions or chess moves as a basis for the elaboration of didactic metaphors capable of creating dynamic learning environments. What is really interesting about this activity is its dynamism, its participative character, its spontaneity and its originality. The aim is not an indepth analysis of the technical and legal elements that govern legal argumentation, but rather to point out the importance of the correct structuring of legal discourse from a strategic point of view and the importance of argumentation for Law.

Chess can be useful when deducing the general features of legal argumentation. These positions invite us to reflect on basic aspects of Law 
and legal argumentation in a fun, reflective and collective way. Aristotle compared rhetoric with an art of action and said that arguments must be meditated upon, divided into distinct parts and accommodated to a certain chosen, appropriate and select eloquence. This definition is a good starting point for a reflection on how to develop a sound legal argument. From the Aristotelian rhetoric perspective, style defines the norms by which a discourse must be governed and taken to practice. It is equally important to have the means of persuasion, that is to say, having logical cognitive elements from which one can deduce the consequences or reasons to demonstrate a proposition, as well as the ability to present them in a dignified and noble eloquent discourse.

\section{References:}

1. ACIEGO, R.; GARCÍA, L.; BETANCORT, M. (2012) The Benefits of Chess for the Intellectual and Social-emotional Enrichment in Schoolchildren, The Spanish Journal of Psychology, $\mathrm{n}^{\circ} 15$ (2).

2. ANGELO, T.A.; CROSS, P. (1993) Classroom Assessment Techniques: A Handbook for College Teachers, Jossey-Bass Publishers.

3. ATIENZA, M. (2006) El Derecho como argumentación: concepciones de la argumentación, Ariel.

4. DUNN, J. (2011) Gradient Semantic Intuitions of Metaphoric Expressions, Metaphor and Symbol, 26: 53-67, Psychology Press, Taylor \& Francis Group.

5. FERNÁNDEZ, F.J. (2010) El ajedrez de la filosofía, Plaza y Valdés.

6. FERNÁNDEZ, J. (2016) Las transversalidades del ajedrez, Balágium.

7. GARCÍA, L. (2013) Ajedrez y ciencia, pasiones mezcladas, Crítica.

8. GLIGA, F.; FLESNER, P.I. (2014) Cognitive Benefits of Chess Training in Novice Children, Procedia - Social and Behavioural Sciences, 116.

9. GRACIÁN, B. (1647) Oráculo manual y el arte de la prudencia, Edition of DÍEZ, J.L. (1993), Ediciones Temas de Hoy.

10. KÖVECSES, Z. (2010) Metaphor: A Practical Introduction, Oxford University Press.

11. LAKOFF, G.; JOHNSON, M. (1999) Philosophy in the Flesh. The Embodied Mind and Its Challenge to Western Philosophy, New York: Basic Books.

12. MARSH, H.W. (1982) SEEQ: A Reliable, Valid and Useful Instrument for Collecting Students' Evaluations of University Teaching, Br. J. educ. Psychol., 52.

13. NIMZOVICH, A. (1925) Mein System, Hays Publishing, new edition (1991). 
14. NUNN, J. (2003) Learn Chess Tactics, Gambit Publications.

15. POSTMA, H.F. (2004) Ajedrez y proceso civil: tácticas y estrategias comunes, in, BARBERÍO, S.; CARRILLO, H.; GARCÍA, M. (Eds.) Doctrina y jurisprudencia civil y comercial.

16. ROSS, A. (1958) On Law and Justice, The Lawbook Exchange.

17. ZAPATERO, V., GARRIDO, M ${ }^{\mathrm{a}}$.I. (2007) El Derecho como proceso normativo. Lecciones de teoría del Derecho, Universidad de Alcalá 